\title{
Reformation and scientific revolution: Historical coincidence or continual renewal?
}

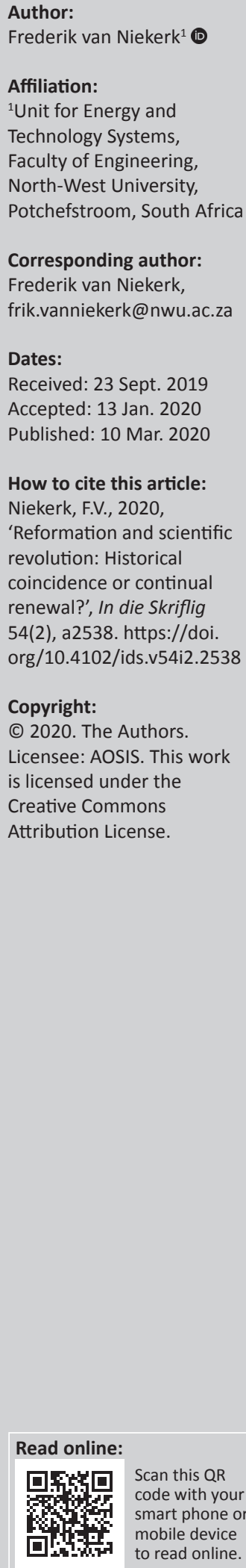

The Reformation and scientific revolution are characterised by an overlap in time, location and a special locus of events that dramatically impacted world history. Precursors for both movements abound, yet the historiographic development characteristics of the era are prominent and distinguishable. The historical context and the developments leading to the Reformation and scientific revolution, specifically the influence of the precursors of both the Reformation and scientific revolution, the prevailing Zeitgeist, the influence of the institutionalised church and ecclesiastical authority, pervasive beyond the realm of the church, the philosophical and theological paradigms of the time and the influence of the press, are appraised to determine the mutual influence of the Reformation and the scientific revolution. The basis for a causal relationship between the Reformation and the scientific revolution is presented, and explanations premised on mere coincidence and other factors are refuted. The continued mutual influence between ideas of the Reformation and science throughout the Enlightenment and modern era is discussed in relation to the interaction between science and faith. It is argued that a mutually supportive model of interaction in a reconciliation model best resonates with the ideas of the Reformation as well as finding authenticity in and concordance between science and views of scripture.

Keywords: Reformation; Scientific revolution; Protestant; Puritan; Science and religion; Hermeneutic renewal; Science-faith; False dichotomy; Scientism.

\section{Introduction}

The Reformation (from 1517) and the scientific revolution (c. 1550-1700) overlapped in time and occurred mostly in the same geographic locations. During this era, social and intellectual life was dominated by religious institutions and ideas espoused by the church. The era is characterised by dramatic developments in science and religion (even religious wars). A fundamental re-thinking of the understanding of Scripture and hermeneutics as well as the concomitant questioning of the status quo regarding authority, specifically the authority of the church, coincided with scientific discoveries and a profound change in the underlying philosophy and approach in conducting science. These developments had (and still have) a dramatic impact on world view.

Were the Reformation and scientific revolution merely coincident amidst other factors rendering a Zeitgeist conducive to reform, even revolution? What impact did the precursors to the Reformation have? What was the influence of the Reformation on the new science? What impact did the new science have on doctrine and hermeneutics, especially during the age of religious warfare that coincided with the scientific revolution? What were the implications on world view and what are the implications today?

\section{Seminal events}

The Reformation is generally considered to have taken off with the seminal event in 1517 when Martin Luther nailed his Ninety-five Theses to the door (bulletin-board of the day) of the All Saints' Church in Wittenberg, Germany. These theses embodied a fundamental reform in understanding Scripture and challenged the prevailing theological doctrine. Luther proclaimed inter alia (i.a.) the authority of the Bible instead of that of the institutionalised church, salvation only through faith and the priesthood of all believers. Luther challenged endemic degeneracy in the church and the abusive influence of ambitious political rulers to which the church had become prone. The church at first did not respond to Luther's request for a disputation. He openly rebuffed the pope's authority a few years after the publication of his theses. The Reformation (Lutherans and later Note: Special Collection: Impact of Reformed Theology. 
followers of John Calvin) resulted in bitter wars against Catholicism for about one and a half centuries, in many regions across Europe.

The scientific revolution coincided with the period of the Reformation around the early 16th century. Nicolaus Copernicus's De revolutionibus orbium coelestium [On the Revolutions of the Heavenly Spheres], published in 1543, is generally regarded as the seminal event associated with the onset of the scientific revolution (Somervill 2005; Copernicus 1543). The works of Francis Bacon, credited by many as the developer of the scientific method and as being the founding father of empiricism, also had a significant impact on the scientific revolution (Matthews 2008). Following the scientific revolution that unfolded in Europe after the Renaissance during the early modern period, modern science emerged and blossomed in several scientific disciplines, until the late 18th century, influencing the philosophical movement known as the Age of Reasoning or Enlightenment.

\section{Precursors}

Historians recognise that throughout the middle ages and during the time of severe moral and institutional decay in the church, there were many independent religious groups with ideas foreshadowing the Reformation, scattered across Europe. These pre-Reformation movements, including movements started by Peter Waldo (c. 1140-1205), John Wycliffe (c. 1320-1384) and Jan Hus (c. 1369-1415), strove to return to the purity of the Apostolic Church. Their religious convictions are recognised as precursors to Protestant ideas (Broadbent 1931).

Although Nicolaus Copernicus's De revolutionibus orbium coelestium, published in 1543, is considered a seminal event earmarking the beginning of the scientific revolution, both Archimedes and Copernicus attributed the heliocentric theory to Aristarchus of Samos, the Greek philosopher and astronomer (c. 310-c. 230 BC) (Kish 1978). Copernicus' publication influenced i.a. Kepler's New Astronomy (1609), Galileo Galilei's discovery of the telescope (1610) and Isaac Newton's Principia (1687).

It follows that the ideas surrounding the Reformation and heliocentrism were not unique to Luther and Copernicus. Until these seminal events, which spurred the Reformation and scientific revolution, the church could moderate or contain deviations from prevailing and pervasive mainline theology and natural philosophy. This time ecclesiastical authorities were unable to contain the impact with which new concepts and ideas were convincingly catapulted into the public domain, when the drama unfolded around Luther and Copernicus, a drama highlighted by the prevailing Zeitgeist and their ability to communicate widely and effectively by virtue of the newly developed printing press. Both the Reformation and the scientific revolution erupted in a manner reminiscent of a revolution.

\section{More than religious reform}

During the middle ages and early modern period, natural philosophy, the study of nature, was embedded in prevailing philosophy and the views of Scripture. At the time of the Reformation, the Aristotelian world view (of which the church had adopted major parts) prevailed. Aristotle had provided the framework for the natural philosophy that underpinned scientific knowledge. This entanglement had a fundamental effect on the prevailing natural philosophy at a time when the influence of the church was pervasive. Ecclesiastical authority determined both the understanding of Scripture and hermeneutics and the philosophic framework defining doctrine and world view (Harrison 2010).

Notwithstanding Aristotle's theological ideas, the Roman Catholic Church had adopted the philosophical tenets of Aristotle as its official natural philosophy. Aristotelianism dominated intellectual life in Europe. In Aristotle's view, rationality far outweighed sensorial considerations resulting in his natural philosophy being based primarily on common sense observations without relying on experimentation and measurement. His uncritical approach rendered some erroneous 'principles' that could explain some everyday observations such as the generalisation that heavy objects will always fall faster than light objects. Reformers were disquieted by the pagan influence that they deemed incompatible with Christianity. Reformers regarded Aristotle's ignorance of the biblical fall, denial of the creation (and Creator) of the world, his view of the mortality of the soul and eternity of the world, as constituting pagan influence. The Catholic Church condemned any deviations from its dogma, such as the mechanical philosophy of René Descartes (which contributed to the philosophical foundations of the new science) because of its emphasis on the quantifiable (Harrison 2010).

A central question that arose was whether the Protestant Reformation encouraged the embracement of the book of nature (a term used to denote the study of nature by Galilei, Bacon and others) instead of the books of Aristotle.

\section{Coincidental correlation or causal relationship?}

Many researchers argue that the conjunction of Reformation and the rise of modern science is not coincidental. Davis and Winship (2017) contend that the Solas of the Reformation (Sola Fide, Sola Gratia, Solus Christus, Sola Scriptura and Soli Deo Gloria), emphasising the sovereignty of God, the enlightening power of the Holy Spirit and accepting the authority of the Bible over Roman Catholic doctrine, not only shaped the understanding of Scripture and hermeneutics but also influenced scientific interpretation (Davis \& Winship 2017). At that time, the vast majority of renowned scientists were deeply religious and often simultaneously were scientists, mathematicians and philosophers. 


\section{Puritanism in England}

The Puritans in England functioned as a convenient group for inferring the historiographic influence of Protestantism on the rise and development of science. This inference is based on i.a. the fact that their scientific and theological contributions to the embryonic activity of the Royal Society have been well documented.

Stimson (1935) contends that Puritanism in England was conducive to the eruption of science at the onset of the Reformation and scientific revolution. This eruption stemmed from the emphasis on uprightness of character, the right of private judgement, assertion of an independent and critical spirit, acquisition of knowledge and application of reason, and its demand for productive activity (Stimson 1935, 1948). Stimson's thesis is premised on the inferred religious associations of the founding members and early membership of the Royal Society. McKie (1960) questions whether Stimson's analyses provide sufficient evidence for attributing the society's incorporation of primarily Puritanism.

Jones $(1936,1939)$ attributes the influence of Puritanism or Protestantism and the onset and rapid growth of the new science in England to the group of 'scientifically minded Puritans' during the so-called 'Puritan era' in England. They espoused the advancement of learning and piety, rejected the authority of Aristotle and strove to promote science.

Merton (1936) ascribes 'the Puritan ethic, as an ideal-typical expression of the value-attitudes basic to ascetic Protestantism ... to constitute an important element in the enhanced cultivation of science'. Turner (1949) studied the relationship between Puritanism and the new awakening in science during the first century of the Reformation and summarised his view by describing Puritanism as 'the essence of Protestantism'. As part of his thesis, Turner listed a number of contemporary scientists (including Boyle and Newton) as being Puritans.

\section{Protestantism in Europe}

Alphonse De Candolle (1873) analysed the historical development of the sciences between 1666 and 1869 . He statistically classified the internationally recognised European scientists according to religious belief as well as education, race and language. Based on religious belief, the representation amongst Protestants was more than seven times higher than that amongst Roman Catholics; Protestants comprised a disproportionally large section of the internationally recognised European scientific community during the period under consideration. De Candolle (1873) attributed this discrepancy to the fact that Reformists grew up in an atmosphere atmosphere where individual free choice prevailed (under less authoritarian dominance) conducive to curiosity-driven research and exploration.

Pelseneer (1946:246) analysed the scientific output of European scientists during 1521-1600 and found a similar disproportionately high output by scientists who were
Protestant believers or sympathisers. He concluded that 'modern science was born of the Reformation'. Taylor $(1968: 82,87)$ regards Reformation theology to be 'monolithically Calvinist', being the 'prime mover in the development of modern science'. Mason (1953a, 1953b, 1956) supported the significance of Calvinist theology in developing harmony between science and religion. According to Mason, scientifically minded Puritans (e.g. Boyle, Sprat and others) rejected the biblical literalism, characteristic of early Protestantism, with the outcome that 'modern science and Calvinist theology reached a modus vivendi and some degree of integration'. Westfall (1958) highlights proposals by scholars to seek a state of co-existence and harmony between the two areas of knowledge.

\section{Protestant work ethic}

Merton (1936) argued that science was spurred by a Protestant or Puritan 'ethic' or 'ethos' associated primarily with Calvinism, an approach that extended Max Weber's assertion that a Protestant 'ethos' had induced the growth of capitalism (Green 1959; Weber 1930). While several scholars pointed out that none of the tenets of Catholicism, Protestantism or Puritanism rendered any of them more conducive to science than the other, Kocher (1953:210) suggested that the Calvinist scientific ethic 'saved Calvinism from scepticism about natural science'. Rosen (1944:375) asserted that 'it may be asserted without contradiction that Puritanism was one of the major motive forces of the new experimental science'.

Ernst Benz (1964:241) stated that 'Christian beliefs provided the rationale, and faith the motive energy for Western technology'. To Benz, and others like Mangalwadi (2011), the early agricultural technological achievements of medieval monasteries are directly attributable to the monastic movement. Their achievements included the plough, water wheel, the crank and the flywheel, which was developed by the German monk Theophilus, who was also an accomplished metallurgist, craftsman, stylish writer and theologian. The monastic movement may be characterised as 'a quest for authentic, biblical Christianity. It followed the Bible in exalting the virtue of manual labour, as well as cultivating a love for God's Word' (Mangalwadi 2011:109).

\section{Protestant-Puritan ethic theory criticism}

Although Kemsley (1968) conceded that Protestants had a significantly higher preference for studies on nature than Roman Catholics during the period under consideration, he presented a number of arguments that challenged the 'Protestant-Puritan ethic theory'. According to Kemsley (1968), Mason fails to relate 'scientific mind' to Calvinism and confuses non-literalism with the idea of accommodation, and in thinking that the idea originated in mid-17th-century England. Kemsley (1968) denies the influence of the Puritans on science, i.a., based on the pre-existence of scientific advances.

It should however be noted that the Roman Catholic authorities were not willing to accept the notion of 
accommodation (Galilei 1842), rendering Kemsley's assertion moot - Kemsley (1968) stated that:

$[A]$ ccepting new theories and discoveries presented no difficulty to those willing and able to accept the explanation of God's 'accommodation', and with it the unspoken corollary of a present revelatory process, while those who attempted to confine God's revelatory activity to the biblical period found either the biblical or the scientific knowledge untenable, and became in consequence either atheistic scientists or anti-scientific churchmen'. Kemsley seems to invite a conciliatory approach between view of Scripture and the new science, something the church was not ready to venture into at the time. (n.p.)

Kemsley (1968) further questions correlations and inferences made by proponents of the Protestant-Puritan ethic theory, based on i.a. the interchangeable and historically undefined use of the terms 'Protestant', 'Puritan' and 'Calvinist'. Similarly, he criticises the regular use of phrases 'glory of God' and 'the benefit of mankind' as attributable primarily to Puritans in particular and Protestants in general. $\mathrm{He}$ furthermore questions a causal connection between the Puritan era and the rise of modern science and the associated significant increase in the scientific literature output devoted to scientific subjects. The inference of the 'Protestant-Puritan ethic theory' from the activities of the embryo Royal Society alone may indeed be challenged on the sample size and factors mentioned by Kemsley; however, he did not take into consideration other studies (e.g. the studies by Alphonse de Candolle [1873], Pelseneer [1946] and others).

Kemsley (1968) asserts (in unconvincing arguments) that the Protestant-Puritan ethic theory is influenced by various considerations:

1. the efforts of the Roman Catholic Church, prior to the Reformation, to promote science

2. the 'neutrality' clauses in the Royal Society's founding documents

3. Francis Bacon's absolute distinction between the Bible ('book of God's words) and nature ('book of God's works')

4. earlier attainments by 'non-Christians'

5. the well-known and recognisable actions by an influential section of Anglicans against the Royal Society. Kemsley asserts that other religious persuasions also exhibited the scientific spirit characteristic of the scientific revolution

6. the fact that Sprat did not attribute the Reformation or advances in theology or science to any denomination or group or its ethos (Sprat 1959).

Dawid Wootton (2017) also disagrees with Merton's (1936) thesis by denying a causal link between the development of the new science and the Reformation. Wootton asserts that the claims are weakened by several factors. Firstly, a number of prominent scientists (e.g. Copernicus, Galilei, Pascal and Descartes) were devout Catholics. Secondly, several prominent Protestant mathematicians were employed by Catholic authorities and, thirdly, the fact that scientific work was shared between Protestant and Catholic scientists.
By calling Copernicus, Galilei, Pascal and Descartes devout Catholics, Wootton (2017) hardly refutes the causal link between the scientific revolution and the Reformation. The statement is as disingenuous as rescinding the Reformation because Luther was Catholic. In 1616, the church officially forbade the study of Copernicus' ideas. Galilei was tried by the Roman Inquisition in 1633 and was found 'vehemently suspect of heresy' and until his death in 1642 he was kept under house arrest (Finocchiaro 1989). Blaise Pascal has been called '... too Protestant for Catholics and too Catholic for Protestants. Yet he's not somewhere in the muddled middle' (Kreeft 1993:13). After Descartes' meeting with Cardinal Berulle in 1628 it was found that (Watson 2002):

$[W]$ ithin weeks Descartes was about as far away from militant Catholicism as you could get in Europe in the seventeenth century, standing on the steps of a Protestant university founded in 1585, and known as a haven for Protestants from all over Europe. (p. 24)

In Wootton's (2017) opinion, the Reformation delayed or retarded the scientific revolution, also because of the fact that the church became more dogmatic in response to novelty. Following the publication of Luther's theses, the Council of Trent (1545-1563) tightened up doctrine. Dogma and doctrine left little freedom for novelty or exploration of new ideas, which was an attribute of the new science. Ultimately, the church condemned Copernicus and his heliocentric cosmos as heretical. Wootton (2017), while noting that the Catholic Church never rejected Darwinism, attributes the conflict between Protestant fundamentalism and Darwinism to the fact that, in his view:

[T] here is no straightforward match between Protestantism and scientific values ... What happened in the scientific revolution was that science developed its own procedures and modes of enquiry and thus established its independence from both philosophers and theologians. (n.p.)

Wootton (2017) seems to ignore the spurring events that had led to the development of 'own modes of enquiry' and implicitly recognise the suppressive capacity (on the development of science) of the church at that time.

\section{Hermeneutics}

The major reformers (including Luther, Calvin, Melanchthon and Bucer) had a clear predilection for the natural, literal interpretation of Scripture, 'combined with suspicion of allegory' (McGrath 1987:171). Luther (1955) contended that 'the simplest meaning as far as possible' should be the basis for interpreting Scripture and that the literal discernment was 'the highest, best, strongest, in short the whole substance, nature and foundation of the holy scripture' and that allegorical studies were for 'weak minds' and 'idle men'. Luther (1520) criticised Origen for 'ignoring the grammatical sense ... he turned trees and everything else ... into allegories'. Calvin (McNeill 1960) argued that 'allegories ought to be carried no further than Scripture expressly sanctions: so far are they from forming a sufficient basis to found doctrines upon'. Based on the view of Scripture espoused by Luther and Calvin and the 
works of several other reformers, Hans Frei (1974:37) observed 'the affirmation that the literal or grammatical sense is the Bible's true sense became programmatic for the traditions of Lutheran and Calvinistic interpretation'.

Harrison (1998) argues in favour of an indirect influence of Protestantism on the development of modern science. Although it is often thought that the light shed by the scientific revolution led to disbelief in the Bible, Harrison believes the contrary is true and contends that when the Bible was read according to the new perspectives, believers felt compelled to jettison traditional concepts of the world. The essence of Harrison's (1998) thesis is that he identified the Protestant approach to the interpretation of texts as being the major catalyst in the emergence of science.

Harrison (1998) contends that Protestant exegesis and hermeneutics are a central feature of the Reformation. According to the Protestant doctrine of the priesthood of all believers, all believers have direct access to the Bible, without enslavement to adulterated interpretations and dogmatic prescripts or the censorship of ecclesiastical authorities. Associated with this new freedom came the quest to escape the confines of the prevailing Aristotelian scholastic philosophy, which ultimately led to experimentation and scientific inquiry. The prevailing hermeneutical frameworks of the time had led to doctrines that over-emphasised symbolism in the church and which had rendered a doctrine and practices unacceptable to the Protestants.

Richard Westfall (1958) and others suggest that certain aspects of the Reformed theology spurred the emergence of a deterministic view of the universe, a basic prerequisite for scientific investigation. Features of Protestant theology identified by Westerfall (1958) and others include the demystification of the world, scepticism about Catholic sacramental magic and miracles, and rejection of the special status of priests, saints and supernatural intermediaries.

The biblical description of a human fall from perfection was a major criticism of Aristotelian scholasticism. While medieval Christians had acknowledged the fall (and its consequences), Luther and Calvin contended that the fall had implications not fully incorporated in the content and conducting of the sciences. Luther stated, 'it is impossible that nature could be understood by human reason after the fall of Adam' and Calvin asserted that because of original sin, 'the whole soul is vitiated'. The fall resulted in moral incapacity, in a comprehensive decline in reason, compassion and conscious awareness. This impact of our 'total depravity on our knowledge-making faculties had been unknown to Aristotle and underestimated by his medieval adherents'. Harrison (2017) asserts that although:

$[N]$ either Luther nor Calvin was particularly concerned with applying this theologically motivated scepticism to the study of nature... But as it turns out, this distinctive theological anthropology opened up a whole range of new possibilities for scientific knowledge. (p. 1)
The tradition of a more literal interpretation of Scripture prevailed in reformed churches after the Reformation. The degree of the literalistic approach varies between reformed denominations, and seems to have evolved over time as hermeneutics in the reformed churches evolved. I contend that this evolvement has been strongly influenced (and continues to be influenced) by the continued and now exponential growth of science in all branches.

\section{Zeitgeist}

The Reformation represented a fundamental challenge to the authority of the church by questioning its view of Scripture and corrupt practices within the church. This laid the table for subjecting the philosophical tenets of the church also to scrutiny, thereby promoting reforms in science.

Scholars who rejected any relationship between Puritanism and science include Knappen (1939), Curtis (1959) and Rabb (1962), who attributed the coincidental Reformation and the rise of science as stemming from a common cause, a religious and philosophical 'spirit of revolution', conveniently providing the impetus for adopting a Baconian philosophy. Similarly, Hill (1965) supports the idea of an underlying 'revolution', as having led to concurrent reconstructions in science, history and law.

Christopher Hill (1964:180) contends that 'what mattered for the development of science was not so much the Protestant doctrine ... as the breaking of clerical monopoly control'. Hill's argument is in line with Richard Greaves' (1969:368) contention that although the Puritan revolution was conducive to the development of (experimental) science, the Puritanism-science relationship 'is not a direct one. The mediating link is revolution'.

Wootton refutes the rejection of Aristotelianism by Protestants, based also on the continued infusion or remnants of Aristotelian philosophy in many European universities, until well after the beginning of the Reformation. In 1621, a natural philosophy chair was established at Oxford. The new physics and astronomy and its philosophical underpinnings were taught by mathematicians Galilei, Kepler and Newton. Given the pervasive influence of ecclesiastical authorities on society, and the fact that the Reformation developed along less revolutionary lines in some contexts, this statement is not a significant general refutation of the rejection of Aristotelianism by the Protestants. Wootton further contends that Catholics also embraced the new science. He uses the fact that Protestant theologians censored Kepler' attempts to reconcile heliocentrism with the Bible, whereas Kepler's work was later published under a Catholic Roman Emperor. These statements are insignificant against the wave of the new science, generally embraced and promoted by Protestants, disproportionately represented amongst eminent scientists of the time. 
In Wootton's (2017) view, a culture of 'openness and intellectual diversity' prevailed after the restoration in England, which was more significant than the religion of the scientists of the day:

If England led the way in promoting the new science, the relative openness and intellectual diversity of its culture after the restoration of the monarchy in 1660 is more significant than the religion of its scientists. (n.p.)

This was however more than a century and a half after the recognised beginning of the Reformation, hardly evidence to refute the arguments in favour of a causal link between the Reformation and the new science.

Wootton (2017) asserts that the scientific revolution was caused by three developments: the influence of the newly developed press, the new mathematically infused scientific method and a climate of discovery amidst the time of exploration. At the time of discovery of the new world, European languages had no word for discovery. The discovery voyages, followed by other developments such as the invention of the telescope and barometer, finally attenuated the influence of Aristotelian philosophy and Ptolemaic astronomy.

Wootton (2017) identifies the development of mathematics as key to the onset of the scientific revolution. Mathematicians assert that mathematics (and the development of the experimental method) provides a better understanding of the world than philosophy. Wootton (2017) contends:

If the scientific revolution is properly called a revolution, it is because of that: the mathematicians seized power and prestige from the philosophers. The challenge is in the full title of Newton's Principia: Philosophiæ Naturalis Principia Mathematicathe mathematical principles of natural philosophy. (n.p.)

Galilei (1842) was undoubtedly one of the 'giants' on whose shoulders Newton stood, stated that:

Philosophy [nature] is written in that great book which ever is before our eyes - I mean the universe - but we cannot understand it if we do not first learn the language and grasp the symbols in which it is written. The book is written in mathematical language ... (n.p.)

However, at the time of the Reformation and scientific revolution, most eminent scientists were simultaneously philosophers, theologians and mathematicians - they could hardly 'seize power and prestige' from themselves.

\section{Differences between East and West}

Modern science originated in Europe and not in China, even though China was more advanced technologically and economically at the time of the Reformation and scientific revolution (Jaki 1977). Rebecca Olerich (2017) provides an appraisal of the Needham Question: '[w]hy didn't China have a scientific revolution considering its early scientific accomplishments?' Joseph Needham (2004) studied and documented eastern and western knowledge extensively, confirming that notwithstanding its earlier scientific accomplishments China never achieved the degree of scientific and technological advancements as did Western Europe in the 16th and 17th centuries.

Needham (2004) supported the idea that the Reformation and the rise of modern science in the West were strongly linked. He also supported Weber's thesis of a causal link between the Protestant work ethic and the rise of modern capitalism. Needham (2004) observed a lack of economic incentive to develop modern science in China because of the lack of a merchant-capitalist system. In China, a centralised bureaucracy administered the state solely to protect imperial power, whereas in the West, societal benefit was acknowledged and spurred scientific knowledge and the application of technological progress.

Elvin (1980) attributes China's stagnation partly to failures of supply technology, a rapid increase in population, constrained industrialisation and technological achievements because of an over-supply of labour. Lin (1995) attributes China's lagging behind the West to its inability to move away from an empirical process of invention to a more scientific innovation process (something the West accomplished through the scientific revolution) and to the prestige attached to the civil service examinations, which stifled learning and the accumulation of scientific knowledge.

\section{The influence of the press}

In Europe, the printing press was developed in 1440 by Gutenburg, greatly enhancing learning and communication. Scholars could compare ancient works and could exchange ideas, observations and experimental results. While in China printing primarily served the authorities of the day, in Europe the printing press fostered individuality. Many scholars, such as Elizabeth Eisenstein (1979), contend that (albeit not the primary cause) the printing press had a significant influence on the development of modern science.

Wootton (2017:455) accredits the development of the printing press as the primary enabler of the scientific revolution in the wake of failing precursors, stating that '[i]f we are looking for the preconditions of modern science, it's to Gutenberg, not Luther, that we should turn'.

The significant influence of the printing press on the Reformation is undisputed, as aptly stated by Davenport (1905):

A man born in 1453, the year of the fall of Constantinople, could look back from his fiftieth year on a lifetime in which about eight million books had been printed, more perhaps than all the scribes of Europe had produced since Constantine founded his city in A.D. 300. (n.p.)

Martin Luther was proficient in using and utilising the power of the printing press. From 1518 to 1525 Luther published almost twice as many works as the next 17 most prolific reformers combined (Bagchi 2016; Edwards 2004). 
It follows that in the West both the scientific revolution and the Reformation were greatly enhanced by the use of printing technology. Printing in China preceded printing in the West by hundreds of years. By AD 972, the Chinese had printed 130000 of the sacred Buddhist writings, the Tripitaka (Mangalwadi 2011). In China, moveable type printing was developed in the 11th century. During the Song Dynasty (1127-1279), printing increased rapidly and served the private and public sectors, also accelerating and encouraging communication and learning, leading to sociopolitical changes directly attributable to the development of printing (Mun 2013). In Korea, moveable metal fonts were invented about two centuries before Gutenberg's invention of the printing press.

Some historians think that printing mandated conformity in China. In China, printing was mostly a means of communicating ideas favourable to the state, and under the prevailing philosophies and prescribed studies favoured by the state at the time (such as Confucianism, Neo-Confucianism and Taoist philosophy), scholars were reluctant to challenge the prescripts of the state or to criticise the ancient writings of their predecessors. The system of civil service examinations had a strong influence on Chinese society (Needham 2004; Olerich 2017). The press never facilitated discourse and a challenge of the status quo as was the case in Europe.

Historians and scholars such as Vishal Mangalwadi (2011:78), an Indian native and familiar with Eastern culture and traditions, refuted Wootton's (2017) argument. Mangalwadi asserted that 'Printing and books did not reform my continent because our religious philosophies undermined reason'. And in his comprehensive appraisal of the influence of the Bible on Western worldview in his book The Book that Made Your World: How the Bible Created the Soul of Western Civilization, Mangalwadi (2011) contends that:

[S]cience flourished in the fertile ground of Christendom because Christians saw that their rational God had made a universe of uniform laws on which men with their own rational minds again in imitation of the mind of the super-intending God could rely. (p. 78)

Mangalwadi (2011:78) noted, as did other historians, philosophers and anthropologists, the virtuous influence of the Christian worldview, in contrast to the influence of the frivolous and capricious Greek and Roman gods and the 'silence in the face of the unknowable' of Buddhism, with their picture of the cosmos that failed to affirm the inherent value of men, whereas 'Christianity certifies this with the doctrine of the Incarnation, in which God's son deigned to become a man for the salvation of mankind'.

\section{Continual renewal}

\section{Enlightenment and modern era}

The Reformation and reformed theology had an indelible influence on world history. It provided the spark for the rising and blooming of science during the scientific revolution, which culminated in the Enlightenment and modern era.
The Reformation ushered in reforms in almost every aspect of society, including science, education, the development of language, the market and the authority of the state. Inadvertently, the first seeds of secularisation were sown when science escaped dogma. Scientifically minded reformists, while rejecting the philosophical influence of the church, wished to return to authentic Christianity which they believed was revealed by the Scripture. The Reformers sought truth and purity in understanding the Scripture as inspired by the Holy Spirit and intended in the writings of the Apostolic Church. They sought purity in understanding nature as the physical revelation given by the Creator.

There seems to be general agreement amongst historians that the origins of the Enlightenment are tied to the scientific revolution. During the ensuing Enlightenment, or the Age of Reason, concepts such as reason, liberty and the scientific method continued to cast a veil of scepticism on institutionalised religion, and supported Enlightenment values of individualism and the power of the human mind, which gave rise to rationalism, empiricism and scepticism (Zalta 1995).

Scepticism towards institutionalised authority was not a reaction against religion per se, neither during the scientific revolution nor during the Enlightenment and Romantic eras. Even Voltaire (1734), one of the most persistent voices against religion during the Enlightenment, directed his criticism against the institutionalised church and not against religion as such. Doctrinal discord and protracted (religious) wars were replaced by philosophical intellectual contentions (Zalta 1995):

[C]ontroversy regarding the truth-value or reasonableness of religious belief in general, Christian belief in particular, and controversy regarding the proper place of religion in society, occupies a particularly central place in the Enlightenment. It's as if the terrible, violent confessional strife in the early modern period in Europe, the bloody drawn-out wars between the Christian sects, were removed to the intellectual arena in the Enlightenment and became a set of more general philosophical controversies. (p. 1)

The Enlightenment ushered in the scientific study of the humanities and gave rise to secular science of man. Many new humanities disciplines arose with the self-assertiveness of humanity as its central theme. During the Reformation and science revolution there was relative harmony between science and religion; humans occupied a special place in nature, created in the image of God. While during the Enlightenment and modern era the sciences continued to blossom, the study of humanity yielded a picture of humanity that drastically deflated its traditional self-image as occupying a special position in nature. The Enlightenment led to the presentation of humanity as a mere natural creature, without free will or an immortal soul.

The controversies of the Enlightenment prevailed throughout the Romantic, modern and post-modern eras. The relationship between religion in general (and reformed theology in 
particular) and science continues to influence the world view. The 'common enemy' is no longer ecclesiastic authority.

\section{Science and religion}

A central question today concerns the contribution of Reformed theology in the science-faith debate and whether there is continual renewal in science and hermeneutics and in the understanding of Scripture. The problem with dogma is that it has a propensity to remain entrenched. Shedding orthodoxy and dogma provided the impetus for science to develop. The notion of the 'Inerrancy of God's Word' is too often replaced by the 'inerrancy of the author'. Literalism is usually at the heart of much of this confusion. I contend that if science, the study of nature (which I believe is part of God's revelation), is considered without perspectives of the scientist, 'pure' science will emerge as being universal and timeless, and given the self-correcting nature of the scientific method, 'pure' science will be orderly, logical and aesthetically consistent. The scientist can however hardly escape the biases of personal philosophical, theological and educational perspectives.

For the Christian scientist, the metaphor of God's two books used by Sir Francis Bacon is as true today as it has been since the days of the 'scientifically minded' reformists during the scientific revolution (Bacon et al. 1884):

Let no man or woman, out of conceit or laziness, think or believe that anyone can search too far or be too well informed in the Book of God's works or the Book of God's words: Science or Religion. Instead, let everyone endlessly improve their understanding of both. (n.p.)

What are the 'endless improvements' of (reformed) theology, amidst rampant scientific development in a secular, scientific age? What is the contribution of i.a. reformed theology in shedding light on what post-modern people experience as inconsistency between science and religion? How is this false dichotomy (the depiction of religion and science as irreconcilable) best exposed in a scientific age where the real conflict is between scientism (coalescing of an atheistic world view with science) and Christian fundamentalism (mostly stemming from a fundamentalist or literalist view of Scripture and/or entrenched orthodoxy and doctrine)? The two books contain complementary, mutually supporting views. Even Einstein, known to be a deist, said ' $r$ ] eligion without science is lame, but science without religion is blind'.

In a further exposition of the influence of religion (reformed theology in particular) and science, it is helpful to consider two frameworks: Mikael Stenmark's (2010:278) four sciencereligion models - based on the fourfold typology provided by Ian Barbour $(1997,2000)$ - and a broad classification of world views with regard to the origins of world view and life by Denis Lamoureaux (2015).

Ian Barbour $(1997,2000)$ proposes a fourfold typology for the interaction between science and religion: conflict (science and religion are mutually exclusive and make competing statements about the overlapping domain, demanding a choice), independence (science and religion do not overlap; each mode of enquiry has its own limitations), dialogue (science and religion have a constructive relationship and seek mutual ground in assumptions, methods and concepts) and integration (mutual interaction and support between science and religion).

Stenmark (2010) refines these ideas and defines four sciencereligion models: the irreconcilability model (conflict is inevitable in overlapping domains while science and religion retain their respective identities), the reconciliation model (science and religion can peacefully co-exist and even enrich and enlighten the human experience), the independence model (science and religion do not overlap because they operate in 'separate magisteria': science operates in the empirical realm, asking questions about the universe's constituents and functional operation, while religion considers meaning and moral value) and the replacement model (gradual replacement of religion by science).

I contend that the reconciliation model resonates best with the ideas of the Reformation - it resonates with the Bible (as exemplified in Ps 19) and the idea of the two books forming part of God's general revelation to man. In the domains of overlap between Scripture and science, any conflict can only be apparent. If science and Scripture have the same author, the revelation will be consistent. Any conflict or inconsistency can only be because of wrong interpretation of Scripture and/or untested or false scientific claims.

The areas of conflict and the influence on world view adopted from Views of the Origin of the Universe $\mathcal{E}$ Life are summarised in Table 1, and adopted from Denis Lamoureaux (2015). Many fine-grain classifications can be provided, but this high-level typology provides a convenient overview for discussing the egressions of the science-religion debate. The first part of the table lists the attributes of Young-Earth Creationists (YEC), Old Earth Creationists (OEC), proponents of Theistic Evolution, deists and atheists in terms of their generalised views of teleology, theology and philosophy, the base of their ethics, the nature of the Bible and a recognition (or denial) of God's activity in the lives of people. These dimensions deal with the spiritual realm and deal with the 'magisterium' of meaning and moral value. These rubrics deal with the 'why?' questions. So far, it could be argued that the views of adherents to Scripture are in relative harmony.

In the next rows in the table, rubrics deal with aspects in the overlap between science and religion. This is typically where science will ask 'what?' and 'how?' questions. This is where a divergence of opinion is evident, not only between the Christians and the atheists (and deists), but also amongst the Christians. The apparent conflict that arises here (notably amongst Christians) deals with the interpretation of Genesis $1-11$, the origin of humanity, the creation of the universe and life. To resolve these apparent conflicts, either underlying (conflicting) scientific theories need revision or verification, and/or the view of Scripture needs further 'reformation'. 

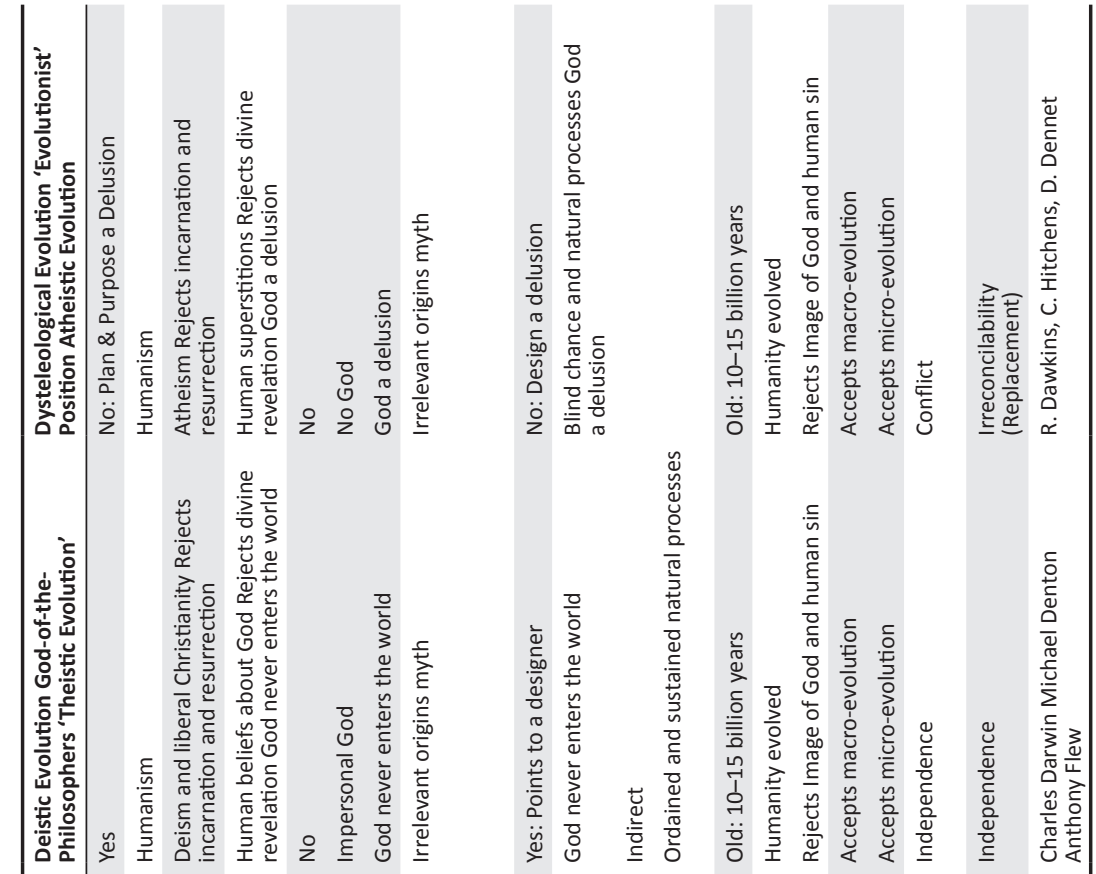

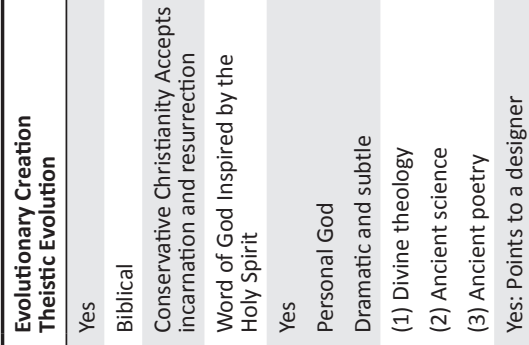
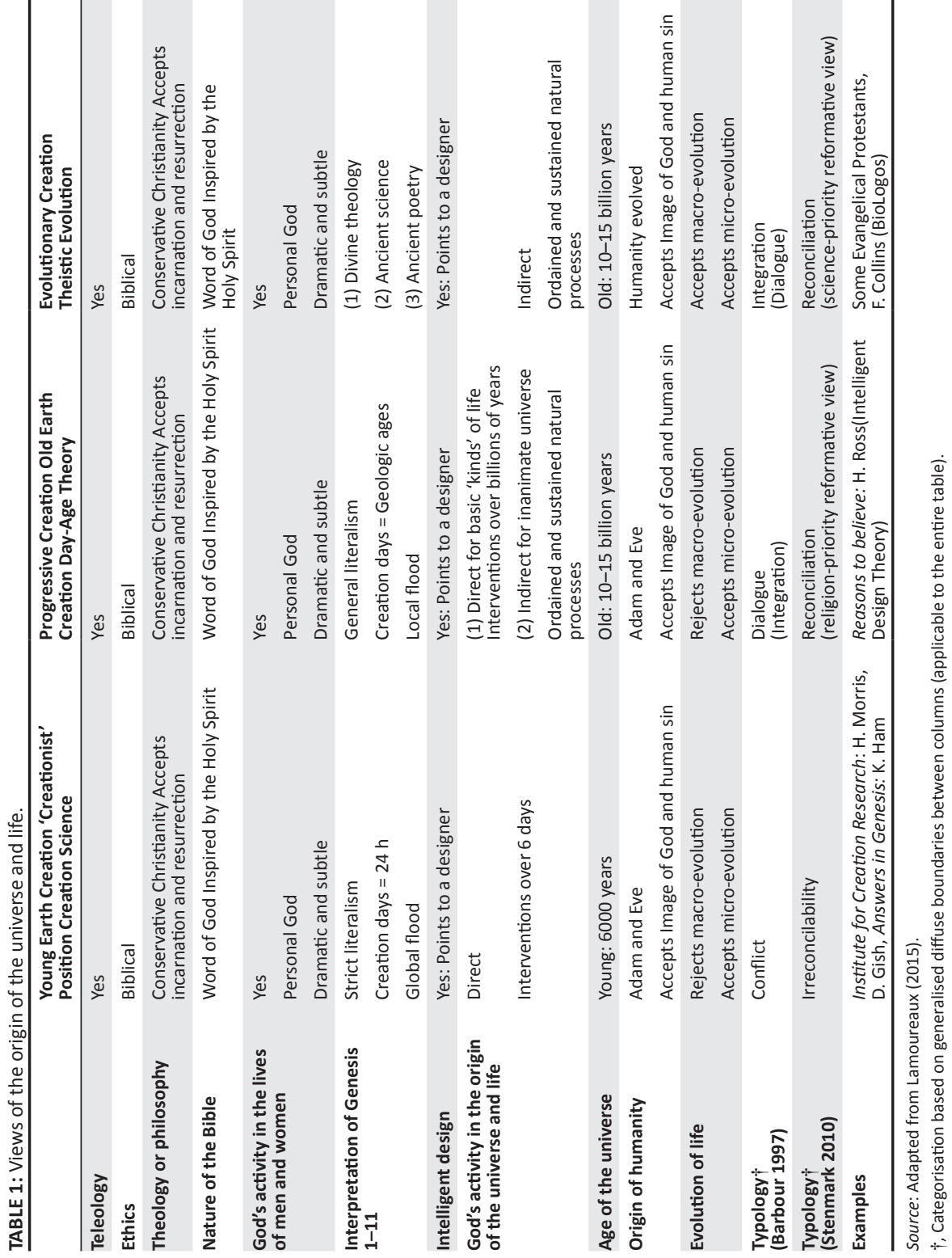


\section{Stenmark (2010) asserts:}

What characterises any reformative view of the reconciliation model is the idea that: Science and religion today can be reconciled if one (or both) changes (or is modified or reformulated) in some way or another. (p. 281)

Stenmark (2010) distinguishes between a religion-priority reformative view and a science-priority reformative view. Reconciliation can occur only if any (or both) of the following is achieved, given any apparent conflicts:

1. Reformation in hermeneutics, including an abandonment of an overly literalist view of Scripture by recognising the use of phenomenological language in the Bible and to invoke a 'suspicion of allegory' in interpreting some Biblical texts. When the Reformers were sceptical of allegorical interpretations of Scripture, as a reaction to the 'glosses' and errant translations of the Bible, did they perhaps go too far in jettisoning allegorical interpretation of some Bible passages?

2. Science should be 'purified' by eliminating untested extrapolations, generalisations, extension of the domain of hypotheses beyond its validity range and personal world view considerations from scientific claims about the area of contention (e.g. origins). Capricious media reports, following scientific breakthroughs or advances, too often feed the false dichotomy between science and religion by extending the implications of scientific advancements beyond limits.

Proponents adhering in general to the first column in Lamoreaux's table (including YECs) maintain a literalist view of Scripture which brings them in conflict with almost all scientific fields dealing with aspects of science, irrespective of centuries of research accumulating vast quantities of supportive evidence.

The area of overlap in science and religion leaves room for a role which is mutually supportive, reinforcing and confirming (Stenmark 2010). In this domain, science (as a continually renewing and self-correcting activity, seeking truth and authenticity in describing nature) and Reformation (as a continually renewing act of seeking truth and authenticity in understanding Scripture) fit into the reconciliation model. Examples include the discoveries of modern science that the universe had a beginning, that the universe is finely tuned for intelligent life to occur. As an example, the intelligent design (ID) movement actively promotes a constructive reconciliatory mode between religion and science. Given the North American secular context, and the movement's desire to introduce ID as a legitimate 'non-religious' scientific theory for origins into the school curriculum (where the de facto approach is humanism and Darwinism, presented as 'science only'), the movement is relatively silent on theological matters. Supporters of attributes in the second and third columns in Lamoreaux's table in general represent a religion-priority and a science-priority reformative view of the intersection of Scripture and science, respectively.
If we are to 'endlessly improve [our] understanding of both' the Book of God's Words and the Book of God's Works, scientists, theologians and philosophers adhering to the two Revelations need to engage in a constrictive balance of a religion-priority reformative view and a science-priority reformative view by seeking purity and truth in a mode of 'continual renewal'. Science is in that mode, by definition. Reformation, more than the event, should continually seek authenticity in hermeneutics and the view of Scripture in a scientific world.

\section{Synthesis and conclusion}

The influence of the Reformation on the scientific revolution (and vice versa!) is evident in more than concurrence and correlation of events. The causal relationship manifests in direct and indirect causal agents. The direct mutual influence is discernible in the characteristic world view of the Protestants in Europe and the Puritans in England, notably their views of Scripture, work ethic and hermeneutics. The disproportionally high representation of Protestant scientists amongst eminent scientists in Europe and England during the time period, characteristic of the Reformation and scientific revolution, is a significant indicator of a causal relationship.

The indirect mutually coherent causal factors include the Zeitgeist and influence of the press. A spirit of underlying revolution and unease with clerical abuse and ecclesiastical authority overlapped with the era of discovery, not only of nature, but also the discovery of the new world. The mental faculties of learned and lay people were unleashed from untested doctrine and dogma. Although Luther and Galilei had been preceded by others, the time was right to overtly challenge ecclesiastic authority. The relatively localised and containable digressions of doctrine prior to the Reformation and scientific revolution could no longer be contained by the church. The epoch-making publications of Luther and Galilei, albeit based on ideas not novel or unique, were catapulted into the public domain by the press, at the right time, and had an effect on every aspect of society. The ensuing conflicts bear testimony to the gravity, even revolutionary nature, of these events.

To attribute the scientific revolution primarily to the press is not convincing. A more established press (China, Korea and India) amidst more advanced scientific and technological developments in other contexts rendered no similar developments. The press was also a key factor in disseminating the ideas of the Reformation, the new philosophy and theology. The press contributed to underline the challenge to ecclesiastic authority and to anchor the reformatory theology and new science in broader society. The press assisted in breaking conformity. The press facilitated the rapid expansion of the Reformation and the new science, underscoring the causal link.

The scientific revolution culminated in the Enlightenment and modern era. During the Enlightenment, religious war and doctrinal discord of the scientific revolution were replaced by philosophical intellectual contentions. While 
science continued to reach new pinnacles, the science of humankind was developed, giving rise to i.a. humanism in an increasingly secular world, rendering a deflated view of humankind's special position in nature, premised on a traditionally held view of the world.

The ideas of the Reformation (only a reflection of a central tenet of Scripture: a constant calling to metanoia and semper reformanda) echo as clearly today as they did during the Reformation, calling for a return to authentic Christianity. The reconciliatory, mutually supporting model of interaction between Science and Religion offers the promise of a world view that is consistent with Scripture and science, provided theologians, philosophers and scientists 'endlessly improve their understanding' of science and Scripture in a process of continual renewal.

\section{Acknowledgements Competing interests}

The author declares that he has no financial or personal relationships that may have inappropriately influenced him in writing this article.

\section{Author's contributions}

F.v.N. is the sole author of this research article.

\section{Ethical considerations}

This article followed all ethical standards for carrying out research without direct contact with human or animal subjects.

\section{Funding information}

This research received no specific grant from any funding agency in the public, commercial, or not-for-profit sectors.

\section{Data availability statement}

Data sharing is not applicable to this article as no new data were created or analysed in this study.

\section{Disclaimer}

The views and opinions expressed in this article are those of the author and do not necessarily reflect the official policy or position of any affiliated agency of the author.

\section{References}

Bacon, F., Spedding, J., Ellis, R.L., Heath, D.D. \& Rawley, W. (eds.), 1884, The works of Francis Bacon, vol. 1, Hurd and Houghton, s.l.

Bagchi, D., 2016, 'Printing, propaganda, and public opinion in the age of Martin Luther', in Oxford research encyclopedia of religion, Oxford University Press, New York, NY. https://doi.org/10.1093/acrefore/9780199340378.013.269

Barbour, I., 1997, Religion and science: Historical and contemporary issues, Harper, San Francisco, CA.

Barbour, I., 2000, When science meets religion, Harper, San Francisco, CA.

Benz, E., 1964, 'Fondamenti cristiani della tecnica occidentale', in E. Castelli (ed.), Tecnica e casistica: Tecnica, escatologia e casistica, CEDAM, Padova.
Broadbent, E.H., 1931, The pilgrim church, Pickering \& Inglis, Basingstoke.

Copernicus, N., 1543, De revolutionibus orbium coelestium, Johannes Petreius, Nuremberg.

Curtis, M.H., 1959, Oxford and Cambridge in transition, 1558-1642: An essay on changing relations between the English universities and English society, Clarendon Press, Oxford.

Davenport, F.M., 1905, Primitive traits in religious revivals: A study in mental and social evolution, Kessinger Publishing, New York, NY.

Davis, E.B. \& Winship, M.P., 2017, 'Early modern Protestantism', in G.B. Ferngren (ed.), Science and religion: A historical introduction, p. 118, Johns Hopkins University Press, Baltimore, MD.

De Candolle, A., 1873, Histoire des sciences et des savants depuis Deux Siècles, suivied'autres etudes sur des sujetsscientifiques, en particulier sur la selection dans l'especehumaine, H. Georg, Genève.

Edwards, M.U., 2004, Luther's last battles: Politics and polemics, 1531-46, Fortress Press, Minneapolis, MN.

Eisenstein, E., 1979, The printing revolution in early modern Europe, Cambridge University Press, Cambridge.

Elvin, M., 1980, 'The work of Joseph Needham', Past \& Present 87(1), 17-20. https:// doi.org/10.1093/past/87.1.17

Finocchiaro, M.A., 1989, The Galileo affair, University of California Press, Berkeley, CA. Frei, H., 1974, The Eclipse of Biblical Narrative, Yale University Press, New Haven, CT.

Galilei, G., 1842, Opere complete di Galileo Galilei, vol. 4, SocietàEditrice Fiorentina, Firenze.

Greaves, R., 1969, 'Puritanism and science: The anatomy of a controversy', Journal of the History of Ideas 30, 345-368. https://doi.org/10.2307/2708562

Green, W., 1959, Protestantism and capitalism: The Weber thesis and its critics, D.C. Heath and Company, Boston, MA.

Harrison, P., 1998, The Bible, protestantism, and the rise of natural sciences, Cambridge University Press, Cambridge.

Harrison, P., 2007, The fall of man and the foundations of science, Cambridge University Press, Cambridge.

Harrison, P. (ed.), 2010, The Cambridge companion to science and religion, Cambridge University Press, Cambridge.

Harrison, P. (ed.), 2017, The Reformation and the Rise of Science, viewed 20 August 2019, from https://www.abc.net.au/religion/the-reformation-and-the-rise-ofscience/10095264.

Hill, C., 1964, 'William Harvey and the idea of monarchy', Past \& Present 27(April), 54-72. https://doi.org/10.1093/past/27.1.54

Hill, C., 1965, Intellectual origins of the English revolution, Clarendon Press, Oxford.

Jaki, S.L., 1977, 'The history of science and the idea of an oscillating universe', in W. Yourgray (ed.), Cosmology, history and theology, pp. 233-251, Plenum Press, New York, NY

Jones, R.F., 1936, Ancients and moderns: A study of the rise of the scientific movement in seventeenth-century England, Courier Corporation, St Louis, MO.

Jones, R.F., 1939, 'Puritanism, science and Christ church', Isis 31(1), 65-67. https://doi. org $/ 10.1086 / 347567$

Kemsley, D.S., 1968, 'Religious influences in the rise of modern science: A review and criticism, particularly of the "Protestant-Puritan ethic theory",', Annals of Science 24(3), 199-226. https://doi.org/10.1080/00033796800200151

Kish, G., 1978, A source book in geography, Harvard University Press, Cambridge, MA. Knappen, M.M., 1939, Tudor puritanism, University of Chicago Press, Chicago, IL. Kocher, P.H., 1953, Science and religion in Elizabethan England, s.n., San Marino, CA.

Kreeft, P., 1993, Christianity for modern pagans: Pascal's pensées: Edited, outlined, and explained, Ignatius Press, San Francisco, CA.

Lamoureaux, D.O., 2015, Views on the origin of universe \& life, viewed 13 August 2019, from https://sites.ualberta.ca/ dlamoure/wlbeyond3/index.html.

Lin, J.Y., 1995, 'The Needham puzzle: Why the industrial revolution did not originate in China', Economic Development and Cultural Change 43(2), 269-292. https://doi. org/10.1086/452150

Luther, M., 1520, Babylon captivity of the church, transl. A.T.W. Steinhäuser, revised by F.C. Ahrens \& Abdel Ross Wentz, viewed August 2019 from http://www. onthewing.org/user/Luther\%20-\%20Babylonian\%20Captivity.pdf.

Luther, M., 1955, 'Answer to the hyperchristian book', in J. Pelikan \& H. Lehman (eds.) Luther's works, vol. 39, Concordia, St Louis, MO.

Mangalwadi, V., 2011, The book that made your world: How the Bible created the sou of Western civilization, Thomas Nelson, Nashville, TN.

Mason, S.F., 1953a, 'The scientific revolution and the protestant reformation, I: Calvin and servetus in relation to the new astronomy and the theory of the circulation of the blood', Annals of Science 9(1), 64-87. https://doi.org/10.1080/00033 795300200033

Mason, S.F., 1953b, 'The scientific revolution and the protestant reformation, II: Lutheranism in relation to iatrochemistry and the German nature philosophy', Annals of Science 9(2) 154-175. https://doi.org/10.1080/00033795300200103

Mason, S.F., 1956, Main currents of scientific thought, Routledge \& Paul, London.

Matthews, S., 2008, Theology and science in the thought of Francis Bacon, Ashgate, Aldershot. 
McGrath, A., 1987, The intellectual origins of the European reformation, Exford, Blackwell. McKie, D., 1960, 'The origins and foundations of the Royal Society of London', Notes and Records of the Royal Society 15(July), 1-37. https://doi.org/10.1098/rsnr.1960.0001

McNeill, J.T. (ed.), 1960, Calvin: Institutes of the Christian religion, vol. 1, transl. and indexed by F.L. Battles, Westminster John Knox Press, Louisville, KY.

Merton, R.K., 1936, 'Puritanism, pietism and science', Sociological Review 28(1), 1-30. https://doi.org/10.1111/j.1467-954X.1936.tb01317.x

Mun, S.-H., 2013, 'Printing press without copyright: A historical analysis of printing and publishing in Song, China', Chinese Journal of Communication 6(1), 1-23. and publishing in Song, China', Chinese Journal
https://doi.org/10.1080/17544750.2013.753497

Needham, J., 2004, The science and civilisation in China: The social background: Volume 7: General conclusions and reflections Part 2, Cambridge University Press, Cambridge.

Olerich, R.L., 2017, 'An examination of the Needham question: Why didn't China have a scientific. revolution considering its early scientific accomplishments?' MA thesis, City University of New York.

Pelseneer, J., 1946, L'Origineprotestante de la science moderne, Uppsala Universtet, Lyehnos.

Rabb, T.K., 1962, 'Puritanism and the rise of experimental science in England', Journal of World History 7, 46-67.

Rosen, E., 1944, 'Left-wing puritanism and science', Bulletin of the History of Medicine $15(4), 375-380$

Somervill, B.A., 2005, Nicolaus Copernicus: Father of modern astronomy, Capstone, Minneapolis, MN.
Sprat, T., 1959, History of the Royal Society, Royal Society, London.

Stenmark, M., 2010, 'Ways of relating science and religion', in P. Harrison (ed.), The Cambridge companion to science and religion, Cambridge University Press, Cambridge.

Stimson, D., 1935, 'Puritanism and the new philosophy in seventeenth-century England', Bulletin of the Institute of the History of Medicine 3(3), 321-334.

Stimson, D., 1948, Scientists and amateurs, Schuman, New York, NY.

Taylor, H.E.L., 1968, 'The reformation and the development of modern science', Churchman 82(2), 87-103.

Turner, C.E.A., 1949, 'Puritan origins in science', Journal of the Transactions of the Victoria Institute 81, 85.

Voltaire (Francois-Marie d'Arouet), 1734, Philosophical letters (Letters on the English nation, letters on England), edited by L. Trancock, Penguin, New York, NY.

Watson, R., 2002, Cogito ergo sum: The life of Rene Descartes, David R. Godine, Boston, MA.

Weber, M., 1930, The protestant ethic and the rise of capitalism, transl. by Talcott Parsons, Scribner, New York, NY.

Westfall, R.S., 1958, Science and religion in seventeenth-century England, Yale UP, New Haven, CT.

Wootton, D., 2017, 'History: Science and the reformation', Nature 550(26 October), 454-455. https://doi.org/10.1038/550454a

Zalta, E.N. (ed.), 1995, Stanford encyclopedia of philosophy, viewed 13 August 2019, from https://plato.stanford.edu/. 